\title{
Tekanan untuk makan dengan kejadian picky eater pada anak usia 2-3 tahun
}

\author{
Pressure to eat with picky eater in 2-3 years old children \\ Carissa Cerdasari ${ }^{1}$, Siti Helmyati ${ }^{2}$, Madarina Julia $^{3}$ \\ ${ }^{1}$ Jurusan Gizi Politeknik Kesehatan Kementerian Kesehatan Malang \\ ${ }^{2}$ Departeman Gizi Kesehatan, Fakultas Kedokteran Universitas Gadjah Mada \\ ${ }^{3}$ Departeman Ilmu Kesehatan Anak, Fakultas Kedokteran Universitas Gadjah Mada / Rumah Sakit Umum Pusat Dr. Sardjito
}

\begin{abstract}
Background: Picky eater is potentially at risk for nutritional deficits. In a long term, this habit could affect child's growth and could lead to malnutrition. Objective: This study was conducted to assess the association of maternal food variation, infant feeding practices, and pressure to eat with picky eating behaviors in 2-3 years old children. Method: In this cross-sectional study, mothers ( $n=141$ ) of children aged 2-3 years old were recruited from 26 integrated health care centers in Gamping, Indonesia between JuniSeptember 2015 using a cluster random sampling method. Picky eater was calculated using child eating behavior questionnaire (CEBQ). Maternal food variation and early age feeding variability data were measured using food variation questionnaire. Data on the pressure to eat were obtained based on subscale pressure to eat in child feeding questionnaire (CFQ). Mann-Whitney test was used to evaluate the association between maternal food variation, infant feeding practices, and pressure to eat with picky eating behavior. Results: Picky eater was significantly associated with mother pressure to eat $(p<0,05)$. There were tendencies of shorter exclusive breastfeeding practice, later in the introduction of solid food, and fewer variability of food at an early age on picky eater, however, there was no significant association ( $p>0,05)$. Conclusion: Mother has a major role in forming children eating behavior. Not pressing children to eat, will protect children from picky eating.
\end{abstract}

KEY WORDS: children 2-3 years old; picky eater; pressure to eat

\begin{abstract}
ABSTRAK
Latar Belakang: Anak picky eater berpotensi mengalami defisiensi zat gizi. Dalam jangka panjang, kebiasaan ini akan mempengaruhi pertumbuhan dan perkembangan anak, serta status gizi anak menjadi kurang. Tujuan: Mengetahui hubungan variasi pangan ibu, praktik pemberian makan saat bayi, dan tekanan untuk makan dengan kejadian picky eater pada anak usia 2-3 tahun. Metode: Pada penelitian cross-sectional ini, ibu ( $\mathrm{n}=141)$ dari anak usia 2-3 tahun direkrut dari 26 posyandu di Puskesmas Gamping II pada bulan Juni-September 2015 menggunakan teknik cluster random sampling. Picky eater ditentukan berdasarkan 5 subskala dalam child eating behavior questionnaire (CEBQ). Data variasi pangan ibu serta variabilitas usia dini diukur dengan wawancara menggunakan kuesioner variasi pangan. Sementara data tekanan untuk makan diperoleh melalui wawancara berdasarkan subskala presssure to eat dalam child feeding questionnaire (CFQ). Uji Mann-Whitney digunakan untuk mengevaluasi hubungan antara variasi pangan ibu, praktik pemberian makan saat bayi, dan tekanan untuk makan dengan perilaku picky eating. Hasil: Tekanan untuk makan secara signifikan berhubungan dengan kejadian picky eater pada anak $(\mathrm{p}<0,05)$. Pada anak picky terdapat kecenderungan riwayat ASI saja yang lebih singkat, usia pengenalan MP-ASI yang lebih lambat, variabilitas pangan usia dini yang lebih sedikit, dan tekanan untuk makan yang lebih tinggi, tetapi tidak ditemukan hubungan yang bermakna $(\mathrm{p}>0,05)$. Simpulan: Ibu memiliki peran besar dalam keberhasilan membentuk perilaku makan anak. Tidak menekan anak untuk makan, menghasilkan anak yang tidak picky eater.
\end{abstract}

KATA KUNCI: anak usia 2-3 tahun; picky eater; tekanan untuk makan

\footnotetext{
Dipresentasikan pada 7th International Symposium on Wellness, Healthy Lifestyle and Nutrition pada tanggal 3-4 November 2016 di Yogyakarta yang diselenggarakan oleh Departemen Gizi Kesehatan, Fakultas Kedokteran Universitas Gadjah Mada, Indonesia kerjasama dengan Universiti Sains Malaysia, Malaysia dan Prince of Songkla University, Thailand

Korespondensi: Carissa Cerdasari, Jurusan Gizi Politeknik Kesehatan Kementerian Kesehatan Malang, Jl. Besar Ijen 77C Malang, Jawa Timur, Indonesia, Telp. (0341) 551896, Fax. (0341) 580228, e-mail: carissa.cerdasari@gmail.com
} 


\section{PENDAHULUAN}

Anak usia 1-3 tahun berada pada masa pertumbuhan cepat setelah masa bayi (1) sehingga membutuhkan dukungan gizi yang baik agar tercapai pertumbuhan dan perkembangan yang optimal (2). Dukungan gizi yang baik diperlukan untuk pertumbuhan anak meliputi berat badan yang meningkat $0,23 \mathrm{~kg}$ dan tinggi badan yang meningkat $1 \mathrm{~cm}$ untuk setiap bulan. Selain itu, asupan gizi harus sesuai dengan kebutuhannya karena dibutuhkan juga untuk perkembangan kognitif dan emosional, serta keterampilan yang meningkat pesat sesuai dengan bertambahnya usia (1). Ibu senantiasa memberikan dukungan gizi yang terbaik bagi anaknya, meskipun pada praktiknya tidak selalu dapat berjalan lancar karena muncul permasalahan yaitu kesulitan makan pada anak. Kesulitan makan pada masa ini kemungkinan terkait dengan penurunan nafsu dan asupan makan yang sejalan dengan penurunan laju pertumbuhan dibanding ketika bayi (1). Kesulitan makan yang sering dikeluhkan terutama dalam hal variasi pangan yang sedikit atau pilih-pilih makanan (picky eating) (3).

Picky eater merupakan masalah yang serius. Tergantung dari metode yang digunakan, prevalensi picky eater bervariasi antara 5,6 sampai dengan lebih dari 50\% (4). Penelitian di Amerika menunjukkan bahwa prevalensi sulit makan pada anak prasekolah terkait picky eater antara lain kurangnya variasi pangan $(58,1 \%)$, penolakan pada sayur, buah, daging, dan ikan (55,8\%), dan kesukaan pada metode pemasakan tertentu sebesar 51,2\% (5). Berdasarkan usia, prevalensinya juga secara konsisten meningkat sejalan dengan peningkatan usia dari 4-24 bulan, yaitu berkisar antara $17-47 \%$ pada laki-laki dan 23-54\% pada perempuan (6). Hasil penelitian di Belanda menunjukkan bahwa prevalensi picky eater tertinggi pada usia 3 tahun $(27,6 \%)$ apabila dibandingkan dengan usia 1,5 maupun 6 tahun (7). Sementara di Indonesia, hasil penelitian menunjukkan bahwa prevalensi balita yang mengalami sulit makan sebesar 23,9\% yang $45,5 \%$ diantaranya adalah picky eater (8).

Kejadian picky eater dapat berawal dari pola makan ibu yang kurang baik sehingga semakin bervariasi makanan ibu, maka anak akan semakin mudah menerima berbagai macam makanan $(9,10)$. Sebaliknya, ibu dengan kebiasaan makan yang buruk juga akan mendapati anaknya lebih suka mengkonsumsi makanan serupa (11). Cara ibu dalam memberikan makan juga memiliki pengaruh pada perilaku makan anak. Tekanan yang diberikan ibu atau pengasuh dalam memberikan makan dapat menyebabkan anak menjadi picky eater (12-14). Pola pemberian makan pada awal kehidupan juga sangat berpengaruh pada perilaku makan anak selanjutnya. Pemberian air susu ibu (ASI) eksklusif sampai 6 bulan, dapat mengurangi kemungkinan anak menjadi picky eater (15). Makanan pendamping ASI (MP-ASI) hendaknya diberikan tidak terlalu dini ataupun terlambat. Pemberian MP-ASI sebelum 6 bulan, akan meningkatkan risiko anak menjadi picky eater sebesar 2,5 kali (5). Idealnya variasi makanan padat hendaknya dikenalkan pada rentang usia 6-9 bulan karena anak akan menjadi lebih pemilih apabila makanan dikenalkan saat usianya lebih dari 9 bulan (16).

Masalah makan pada anak dapat berakibat jangka panjang pada pertumbuhan dan perkembangan. Anak picky eater akan mendapatkan zat gizi dari makanan yang terbatas dalam hal variasinya sehingga berpotensi mengalami kekurangan gizi dan risiko lebih besar pada usia kurang dari 3 tahun (3). Penelitian yang dilakukan di Kanada juga menemukan bahwa picky eater memiki risiko 2 kali lebih besar untuk menjadi underweight pada usia 4,5 tahun dibandingkan anak yang tidak pernah menjadi picky eater (17). Underweight akan mengganggu perkembangan kecerdasan, proses belajar, lebih rentan terhadap infeksi, meningkatkan keparahan penyakit, hingga meningkatkan mortalitas (3).

Penelitian mengenai picky eater di Indonesia terutama di Yogyakarta masih terbatas. Beberapa penelitian mengenai picky eater di Indonesia lebih menghubungkan kejadian picky eater dengan siapa yang mengasuh anak dan perilaku makan orangtua terkait 3J ( jumlah, jenis, jadwal makan) $(8,18)$. Penelitian sebelumnya ini belum menganalisis lebih lanjut mengenai faktor-faktor lain yang berhubungan dengan kejadian picky eater. Oleh karena itu, peneliti tertarik melakukan penelitian guna mengetahui apakah variasi pangan ibu, lama ASI eksklusif, usia mulai pemberian MP-ASI, variabilitas pangan pada usia dini, serta tekanan untuk makan berhubungan dengan terjadinya picky eater pada anak usia 2-3 tahun. 


\section{BAHAN DAN METODE}

Penelitian ini menggunakan rancangan penelitian cross-sectional dan dilakukan di wilayah Puskesmas Gamping II, Kabupaten Sleman, Daerah Istimewa Yogyakarta (DIY) pada bulan Juni-September 2015. Alasan pemilihan tempat berdasarkan data Dinas Kesehatan Provinsi DIY tahun 2013, Puskesmas Gamping II masih memiliki berbagai permasalahan gizi dibandingkan puskesmas lain di Sleman yaitu cakupan ASI eksklusif paling rendah (70,31\%); termasuk dalam tiga besar dengan prevalensi wasting tertinggi (4,53\%); lima besar dengan prevalensi gizi buruk tertinggi $(0,53 \%)$; dan 10 besar dengan prevalensi stunting tertinggi (10,75\%). Lama pemberian ASI eksklusif merupakan salah satu faktor risiko terjadinya picky eating sedangkan status gizi yang kurang dapat merupakan outcome dari perilaku picky eating.

Populasi terjangkau dalam penelitian ini adalah semua anak usia 2-3 tahun yang tinggal di wilayah Puskesmas Gamping II, Kabupaten Sleman, DIY sedangkan subjek penelitian adalah anak usia 2-3 tahun yang tinggal di wilayah Puskesmas Gamping II yang memenuhi kriteria inklusi yaitu: 1) Anak usia 2-3 tahun yang mengunjungi posyandu di wilayah Puskesmas Gamping II; 2) Tinggal bersama ibu dalam 1 rumah; 3) Ibu bersedia mengikuti penelitian dengan menandatangani informed consent. Apabila anak sedang sakit maka tidak diikutsertakan dalam penelitian.

Besar sampel yang dibutuhkan dihitung dengan menggunakan rumus besar sampel (19) dengan mempertimbangkan desain efek sebesar 1,5 (20) sehingga diperoleh 141 anak. Pengambilan sampel dilakukan secara cluster random sampling. Unit kluster dalam penelitian ini adalah posyandu. Jumlah posyandu aktif sebanyak 54 posyandu dengan jumlah total balita usia 2-5 tahun sebanyak 1.688 anak, dengan asumsi jumlah anak usia 2-3 tahun merupakan sepertiga dari data tersebut yaitu 563 anak. Berdasarkan kunjungan awal, ditemukan bahwa anak usia 2-3 tahun yang datang ke posyandu bersama dengan ibunya rata-rata sebanyak 6 anak sehingga untuk memenuhi besar sampel dibutuhkan 26 posyandu. Pada saat dilakukan penelitian, jumlah anak dari 26 posyandu adalah 156 anak dengan jumlah eligible subjek sebanyak 152 anak. Pemilihan 141 anak berdasarkan anak yang terlebih dahulu datang ke posyandu terpilih dan memenuhi kriteria serta telah bersedia menjadi subjek penelitian.

Variasi pangan ibu adalah jumlah jenis bahan makanan maupun kelompok bahan makanan yang dikonsumsi ibu dalam 1 minggu terakhir. Semakin banyak variasi pangan ibu dalam 1 minggu, menunjukkan variasi pangan ibu semakin baik. Variasi makan diukur selama 1 minggu karena rentang waktu 1 minggu (7 hari) dapat menggambarkan kebiasaan makan ibu yang telah terbangun dalam waktu yang lebih lama sebelumnya (21). Lama ASI eksklusif diartikan sebagai usia saat anak terakhir mendapatkan ASI saja tanpa tambahan makanan maupun minuman lainnya termasuk air putih. Usia mulai makanan padat adalah usia saat anak mulai mendapatkan makanan padat sebagai pendamping dari ASI maupun pendamping susu formula. Variabilitas pangan usia dini adalah jumlah bahan makanan yang diberikan kepada anak ketika anak mulai mendapatkan MP-ASI hingga berusia 9 bulan. Semakin banyak bahan makanan yang diberikan pada rentang usia 6-9 bulan, maka variabilitas pangan usia dini semakin baik. Tekanan untuk makan diartikan sebagai cara pemberian makan dengan tekanan saat memberikan makan kepada anak. Tekanan untuk makan diukur menggunakan kuesioner child feeding questionnaire (CFQ) yang terdiri dari 4 pertanyaan yang dinilai menggunakan skala Likert 1-5 dari tidak setuju sampai setuju. Dihitung total skor dan semakin tinggi skor yang diperoleh maka menunjukkan bahwa ibu semakin memberikan tekanan untuk makan pada anaknya (22).

Picky eater diartikan sebagai anak dengan beberapa kriteria perilaku makan seperti cepat merasa kenyang, makan dengan lamban, rewel dan pilih-pilih makanan, kurang respon terhadap makanan, dan kurang menikmati saat-saat makan. Picky eater diukur dengan 5 subskala dalam child eating behavior questionnaire (CEBQ) yang tergolong dalam 2 kategori yaitu food avoidance (satiety responsiveness (SR); slowness in eating (SE); fussiness (FF)) dan food approach (food responsiveness (FR); dan enjoyment of food (EF)) (23) menggunakan skala Likert 1-5 (1=tidak pernah, 2=jarang, 3=kadang-kadang, 4=sering, $5=$ selalu).

Picky eater merupakan kombinasi dari skor food avoidance yang tinggi dengan skor food approach 
yang rendah. Pada kelompok subskala yang bersifat menghindari makan (food avoidance) seperti SR, SE, dan FF, pernyataan yang bersifat positif pada perilaku food avoidance diberikan skor 5 untuk jawaban "selalu", skor 4 untuk jawaban "sering”, skor 3 untuk jawaban "kadang-kadang", skor 2 untuk jawaban "jarang”, dan skor 1 untuk jawaban "tidak pernah". Begitu pula pada kelompok subskala yang bersifat mendekati makan (food approach) seperti FR dan EF, pernyataan yang bersifat positif pada perilaku food approach diberikan skor 5 untuk jawaban "selalu", skor 4 untuk jawaban "sering", skor 3 untuk jawaban "kadang-kadang", skor 2 untuk jawaban "jarang", dan skor 1 untuk jawaban "tidak pernah". Skor dari setiap subskala dikalkulasi sebagai rerata (mean) dan dibandingkan dengan $z$-score masingmasing subskala seperti pada penelitian sebelumnya (4). Dikatakan picky eater apabila memenuhi semua kriteria berikut: 1) Skor $\mathrm{SR}=1,5 \mathrm{SD}$ di atas mean; 2) $\mathrm{Skor} \mathrm{SE}=1,5$ $\mathrm{SD}$ di atas mean; 3) Skor FF=1,5 SD di atas mean; 4) Skor FR=1 SD di bawah mean; 5) Skor EF=2 SD di bawah mean.

Data karakteristik orangtua meliputi usia, pekerjaan, lama bekerja setiap harinya, pengasuh anak ketika ibu bekerja, dan pendidikan orangtua. Pendidikan orangtua dikategorikan menjadi 2 yaitu rendah/menengah (pendidikan dasar sampai SMA) dan tinggi (tamat akademi/perguruan tinggi). Sementara data karakteristik anak meliputi usia, jenis kelamin, status gizi, dan urutan kelahiran dalam keluarga. Status gizi diukur menggunakan indikator berat badan menurut tinggi badan (BB/TB) dengan kategori gemuk (Z score $>2 \mathrm{SD})$; normal (Z score -2SD s.d. +2SD); kurus (Z Score <- 2SD).

Data karakteristik anak dan keluarga dikumpulkan melalui wawancara dengan kuesioner. Kuesioner riwayat ASI, MP-ASI, dan pola pemberian MP-ASI digunakan untuk menggali lama usia ASI eksklusif dan usia mulai makanan padat. Variasi pangan ibu dinilai dengan menggunakan kuesioner pada penelitian sebelumnya (21), tetapi item bahan makanan sudah disesuaikan berdasarkan bahan makanan yang biasa dikonsumsi oleh responden yang diketahui melalui wawancara asupan makan 24 jam. Item bahan makanan dalam kuesioner ini juga sebagai dasar dalam menanyakan variabilitas pangan usia dini.
Teknik wawancara yang dilakukan untuk menjaga validitas data lama ASI eksklusif yaitu selain ditanyakan langsung juga dilakukan cek silang dengan pertanyaan lain seperti kapan anak diberikan cairan lain selain ASI (air putih, tajin, atau madu). Sementara itu, dalam memperoleh data variabilitas pangan usia dini secara valid, maka dilakukan cek secara berurutan bahan makanan apa saja yang dikenalkan mulai usia 0-12 bulan, disamping ditanyakan langsung kapan dikenalkan berbagai bahan makanan yang ada pada daftar variasi pangan.

Sebelum digunakan, kuesioner tekanan untuk makan berdasarkan CFQ dan kuesioner penentuan picky eater berdasarkan CEBQ divalidasi dengan metode forward-backward translation. Kuesioner asli berbahasa Inggris terlebih dahulu diterjemahkan ke dalam Bahasa Indonesia dengan bantuan peneliti ahli dan kemudian diterjemahkan kembali ke dalam Bahasa Inggris oleh pakar Bahasa Inggris. Hasil terjemahan Bahasa Inggris ini kemudian dibandingkan dengan kuesioner asli dan dikirimkan ke peneliti asli penyusun kuesioner CFQ dan CEBQ untuk dinilai kesesuaiannya. Selain itu juga dilakukan uji validitas dan reliabilitas.

Alat penelitian yang digunakan untuk mengukur berat dan tinggi badan anak adalah microtoise dan timbangan digital dengan ketelitian $0,1 \mathrm{~kg}$. Penimbangan berat badan dan pengukuran tinggi badan dilakukan 2 kali dan dihitung reratanya. Pada penelitian ini, tidak dihitung interrater reliability pada pengukuran antropometri. Pengukuran antropometri dilakukan oleh 2 orang enumerator terlatih dengan latar belakang pendidikan S1 Gizi Kesehatan yang dinilai memiliki kompetensi yang sama dalam hal pengukuran antropometri. Pengukuran tinggi badan dan berat badan masing-masing hanya dilakukan oleh satu orang enumerator saja. Secara keseluruhan, penelitian ini melibatkan 3 orang enumerator gizi yaitu 2 orang dengan latar belakang pendidikan S1 Gizi Kesehatan dan 1 orang berlatar belakang D3 Gizi.

Data yang telah terkumpul dianalisis secara univariat untuk melihat gambaran distribusi frekuensi karakteristik responden, variabel bebas, terikat berupa mean, median, dan range sedangkan analisis bivariat untuk melihat hubungan antara variabel bebas dan variabel terikat picky eater menggunakan uji Mann-Whitney. Penelitian 
Tabel 1. Karakteristik umum subjek penelitian

\begin{tabular}{lcc}
\hline \multicolumn{1}{c}{ Variabel } & $\mathbf{n = 1 4 1}$ & $\mathbf{\%}$ \\
\hline Status bekerja ibu & & \\
$\quad$ Tidak Bekerja/ ibu rumah tangga & 110 & 78,0 \\
$\quad$ Bekerja & 31 & 22,0 \\
Pendidikan ibu' & & \\
$\quad$ Rendah/menengah & 116 & 82,3 \\
$\quad$ Tinggi & 25 & 17,7 \\
Jenis pekerjaan ayah & & \\
$\quad$ Buruh/ pedagang/jasa/wiraswasta & 83 & 58,9 \\
$\quad$ Pegawai swasta/BUMN/PNS/TNI/POLRI & 58 & 41,1 \\
Pendidikan ayah ${ }^{1}$ & & \\
$\quad$ Rendah/menengah & 124 & 87,9 \\
$\quad$ Tinggi & 17 & 12,1 \\
Jumlah anak & & \\
$\quad>2$ & 20 & 14,18 \\
$\quad \leq 2$ & 121 & 85,82 \\
\hline${ }^{1}$ Rendah/menengah = pendidikan dasar sampai SMA; Tinggi = tamat \\
akademi atau perguruan tinggi
\end{tabular}

ini dilaksanakan setelah mendapatkan surat kelaikan etik (ethical approval) dengan nomor KE/FK/635/EC/2015 dari Komisi Etik Fakultas Kedokteran Universitas Gadjah Mada tanggal 4 Juni 2015. Pengambilan data pada subjek penelitian dilakukan setelah terdapat kesediaan dengan ditandatanganinya lembar kesediaan (informed consent) oleh subjek penelitian.

\section{HASIL}

\section{Karakteristik subjek penelitian}

Rerata usia anak dalam penelitian ini adalah $29,5 \pm 6,3$ bulan sedangkan rerata usia ibu adalah $31,7 \pm 6,3$ tahun dengan usia paling muda 19 tahun dan paling tua 48 tahun dan rerata usia ayah adalah $34,5 \pm 6,4$ tahun dengan usia termuda 19 tahun dan tertua 53 tahun. Karakteristik umum subjek penelitian yang lain disajikan pada Tabel $\mathbf{1}$ dan karakteristik anak disajikan pada Tabel 2.

Terkait dengan pekerjaan ibu, mayoritas ibu bekerja sebagai pedagang/jasa/wiraswasta dan pegawai swasta, masing-masing sebesar $(45,16 \%)$, hanya 2 orang $(6,45 \%)$ sebagai buruh, dan 1 orang $(3,23 \%)$ sebagai PNS/TNI/POLRI. Rerata lama kerja ibu dalam sehari adalah 6,7 $\pm 2,3$ jam. Selama ibu bekerja, mayoritas anak diasuh oleh nenek $(51,61 \%)$, selebihnya diasuh di tempat
Tabel 2. Karakteristik anak

\begin{tabular}{lcc}
\hline \multicolumn{1}{c}{ Variabel } & $\mathbf{n}=\mathbf{1 4 1}$ & $\mathbf{\%}$ \\
\hline Jenis kelamin anak & & \\
$\quad$ Laki - laki & 73 & 51,77 \\
$\quad$ Perempuan & 68 & 48,23 \\
Status gizi anak berdasarkan $\mathbf{B B} / \mathbf{T B}^{\mathbf{1}}$ & \\
$\quad$ & 10 & 7,1 \\
$\quad$ Gemuk & 121 & 85,9 \\
$\quad$ Normal & 10 & 7,1 \\
$\quad$ Kurus & & \\
Urutan kelahiran anak & 75 & 53,2 \\
$\quad$ Anak pertama & 66 & 46,8 \\
$\quad$ Anak kedua dan selanjutnya & 6 & \\
\hline${ }^{1}$ Gemuk $(Z$ score $>+2$ SD); Normal $(Z$ score -2 SD s.d. +2 SD); Kurus \\
(Z score $<-2$ SD)
\end{tabular}

penitipan anak (TPA) $(9,68 \%)$, bersama ayah $(22,58 \%)$, atau diasuh oleh saudara (16,13\%). Gambaran subjek penelitian berdasarkan status picky eater menunjukkan bahwa sebagian besar anak tergolong tidak picky eater $(97,87 \%)$ dan hanya 3 anak yang mengalami picky eater $(2,13 \%)$.

\section{Variabel yang diteliti}

Rerata variasi pangan ibu tergolong tinggi yaitu sebesar 32,0 05,9 dengan median (Q1:Q3) adalah 32 (22:44). Cakupan ASI eksklusif hanya sebesar 28,4\% dengan median (Q1:Q3) lama ASI eksklusif adalah 3 $(0: 6)$ bulan. Mayoritas ibu memberikan makanan padat mulai usia 6 bulan atau lebih $(72,34 \%)$ dengan rata-rata usia dimulainya makanan padat $5,7 \pm 1,8$ bulan. Median (Q1:Q3) variabilitas pangan usia dini adalah 16 (11:21) dan skor tekanan untuk makan adalah 14 (12:16).

\section{Faktor-faktor yang berhubungan dengan kejadian picky eater}

Hubungan antara faktor risiko dengan status picky eater ditunjukkan pada Tabel 3 di bawah ini. Hasil analisis uji Mann-Whitney menunjukkan bahwa di antara semua faktor risiko yang menyebabkan terjadinya picky eater, hanya 1 variabel saja yang berhubungan secara bermakna yaitu variabel tekanan untuk makan ( $p>0,05)$. Tidak ada hubungan antara variasi pangan ibu, lama ASI saja, usia mulai makanan padat, dan variabilitas pangan usia dini dengan kejadian picky eater $(\mathrm{p}>0,05)$. 
Tabel 3. Perbedaan rata-rata variabel penelitian berdasarkan status picky eater

\begin{tabular}{lccc}
\hline \multicolumn{1}{c}{ Variabel } & Bukan picky eater & picky eater & \multirow{2}{*}{$\mathbf{p}^{\mathbf{3}}$} \\
\cline { 2 - 3 } & $\mathbf{( n = 1 3 8 )}$ & $\mathbf{( n = 3 )}$ & \\
\hline Variasi pangan ibu (jenis $\left.\mathrm{BM}^{1}\right)$ & $32(28 ; 36)^{2}$ & $33(29 ; 38)$ & 0,60 \\
Lama ASI eksklusif (bulan) & $3(0 ; 6)$ & $0(0 ; 4)$ & 0,27 \\
Usia mulai makanan padat (bulan) & $6(5 ; 7)$ & $6(6 ; 7)$ & 0,53 \\
Variabilitas pangan usia dini (jenis BM) & $16(11 ; 21)$ & $11(8 ; 14)$ & 0,16 \\
Tekanan untuk makan & $14(12 ; 16)$ & $20(15 ; 20)$ & $0,03^{*}$ \\
\hline
\end{tabular}

${ }^{1} \mathrm{BM}=$ bahan makanan; ${ }^{2}$ Median $(\mathrm{Q} 1 ; \mathrm{Q} 3) ;{ }^{3}$ Uji Mann-Whitney; ${ }^{*}$ signifikan $(\mathrm{p}<0,05)$

\section{BAHASAN}

\section{Proporsi picky eater}

Proporsi anak picky eater usia 2-3 tahun sebesar 2,13\%. Penelitian di Belanda dengan metode yang sama, menemukan sebesar 5,6\% anak usia 4 tahun yang picky eater (4). Sementara proporsi balita picky eater di Banjarbaru sebesar 10,87\% (8). Perbedaan proporsi ini dapat disebabkan oleh perbedaan tempat penelitian, rentang usia subjek penelitian, dan metode penentuan picky eater yang digunakan. Pada penelitian ini, kriteria yang harus dipenuhi setiap anak untuk dapat dikatakan sebagai picky eater lebih ketat dibandingkan dengan penelitian sebelumnya yang menggunakan skor total dari 52 pertanyaan.

\section{Hubungan variasi pangan ibu dengan status picky eater}

Hasil penelitian ini menunjukkan tidak adanya hubungan signifikan antara variasi pangan ibu dengan kejadian picky eater $(\mathrm{p}>0,05)$. Terdapat perbedaan hasil dengan penelitian sebelumnya yang menemukan bahwa ibu dengan konsumsi sayur dan buah yang lebih banyak, memiliki anak yang lebih tidak pemilih (12). Perbedaan dengan penelitian sebelumnya tersebut kemungkinan disebabkan penentuan picky eater pada penelitian ini tidak hanya dilihat dari sisi kurangnya variasi pangan anak. Picky eater didefinisikan sebagai anak yang memiliki keseluruhan karakteristik, yaitu cepat merasa kenyang, makan dengan lamban, rewel dalam memilih makanan, serta sulit menerima dan menikmati makanan. Dengan demikian, kemungkinan hal-hal lain tersebut yang lebih mempengaruhi terkait kejadian picky eater.

Selain itu, disebutkan bahwa orang dewasa lebih toleran terhadap rasa asam dan pahit (24) dibanding anak yang lebih menyukai rasa manis (25). Anak picky eater kemungkinan kurang memiliki pengalaman penting terkait dengan rasa sedangkan ibu telah memiliki banyak kesempatan untuk mengembangkan daya terima terhadap berbagai rasa (24). Alasan tersebut yang kemungkinan dapat mendasari hasil yang diperoleh pada penelitian ini, mengapa variasi pangan ibu pada anak yang picky eater dengan yang bukan picky eater tidak tampak berbeda.

\section{Hubungan lama ASI eksklusif dengan status picky eater}

Tidak ada hubungan signifikan antara lama ASI eksklusif dengan status picky eater $(\mathrm{p}>0,05)$. Berbeda dengan hasil penelitian di Amerika yang menemukan bahwa ASI eksklusif berhubungan negatif dengan kejadian picky eater pada anak (15). Hasil yang berbeda ini kemungkinan disebabkan oleh perbedaan cara penentuan picky eater. Penelitian tersebut menggunakan rerata skor dari 5 butir pertanyaan berskala Likert dalam kuesioner CFQ dengan hasil sebesar 27\% anak picky eater dibandingkan dengan penelitian ini yang hanya ditemukan sebesar 2,13\% dengan penentuan picky eater yang lebih ketat. Kecilnya proporsi anak picky eater yang didapatkan pada penelitian ini kemungkinan merupakan salah satu penyebab tidak ditemukannya hubungan antara pemberian ASI eksklusif dengan status picky eater. Demikian juga hasil penelitian lain di Amerika yang menemukan bahwa pemberian ASI eksklusif secara signifikan menurunkan risiko penolakan makan pada anak hingga $81 \%$ dan food neophobia hingga $75 \%$. Meskipun demikian, penelitian tersebut juga gagal menemukan hubungan signifikan antara pemberian ASI eksklusif dengan variasi pangan anak (5). 


\section{Hubungan usia mulai makanan padat dengan status picky eater}

Tidak ada hubungan yang signifikan antara usia mulai makanan padat dengan status picky eater $(\mathrm{p}>0,05)$. Didukung oleh penelitian lain yang tidak menemukan hubungan antara usia mulai pemberian makanan padat dengan skor pickiness (26). Kemungkinan terdapat faktor lain yang lebih berpengaruh terhadap munculnya kejadian picky eater terutama apabila dilihat dari segi penerimaan makan pada anak yaitu seperti preferensi makanan. Beberapa studi telah menunjukkan bahwa preferensi anak-anak untuk menerima makanan baru dapat ditingkatkan dengan pengenalan secara berulang, yaitu 8-16 kali pada anak usia prasekolah (27-29).

Namun, hasil penelitian ini tidak sejalan dengan penelitian di Amerika yang menemukan bahwa anak yang mulai diberikan makanan padat saat berusia kurang dari 6 bulan akan lebih memunculkan perilaku picky eating saat menginjak usia prasekolah (5). Ketidaksesuaian dengan penelitian sebelumnya ini kemungkinan dapat disebabkan oleh perbedaan definisi picky eater yang digunakan. Penelitian tersebut meneliti perilaku picky eating berdasarkan 4 faktor yang berbeda, yaitu kesukaan terhadap persiapan dan teknik pemasakan tertentu, penolakan makan, ketakutan terhadap makanan baru, dan variasi pangan yang terbatas. Berdasarkan keempat faktor tersebut, yang berhubungan dengan pengenalan makanan padat sebelum usia 6 bulan adalah faktor ketakutan terhadap makanan baru (food neophobia) dan variasi pangan yang terbatas. Sementara untuk dua variabel lainnya tidak ditemukan hubungan dengan pengenalan makanan padat sebelum usia 6 bulan (5). Penelitian ini mendefinisikan picky eater sebagai suatu kesatuan perilaku yang dicirikan dengan skor perilaku food avoidance yang tinggi dengan skor perilaku food avoidance yang rendah. Perbedaan penentuan picky eater ini yang mungkin dapat menyebabkan hasil yang berbeda.

\section{Hubungan variabilitas pangan usia dini dengan status picky eater}

Tidak ada hubungan yang signifikan antara variabilitas pangan usia dini dengan status picky eater ( $p>0,05)$. Namun, tampak bahwa variabilitas pangan usia dini anak picky eater lebih sedikit dengan rata-rata 11 bahan makanan saja dibandingkan 16,36 bahan makanan pada anak yang bukan picky eater. Penelitian di Inggris menemukan bahwa ibu yang tidak mengenalkan makanan yang bervariasi kepada anak di umur 1 tahun pertama, akan terus tidak melakukannya di sepanjang masa kanak-kanak (16). Salah satu penyebab kegagalan untuk menemukan hubungan antara variabilitas pangan usia dini dengan status picky eater dapat disebabkan perbedaan besar sampel dengan penelitian sebelumnya.

\section{Hubungan tekanan untuk makan dengan status picky eater}

Hasil penelitian menunjukkan bahwa terdapat hubungan antara tekanan untuk makan dengan status picky eater $(\mathrm{p}=0,03)$. Beberapa studi mengungkapkan bahwa pemberian makan dengan tekanan memiliki dampak negatif pada cara makan anak dan keluaran berat badan pada anak (30) serta menyebabkan anak menjadi picky eater (12-14). Ibu seringkali selalu mengatur makan anak agar anak makan dengan cukup dan menghabiskan makanannya, serta berusaha tetap memberikan makan meski anak tidak lapar (22). Cara seperti ini dianggap berhasil meningkatkan asupan makan anak pada saat itu, tetapi tanpa disadari akan memberikan dampak negatif terhadap pola makan anak di kemudian hari.

\section{SIMPULAN DAN SARAN}

Pada penelitian ini tidak ditemukan hubungan antara variasi pangan ibu, lama ASI eksklusif, usia mulai makanan padat, dan variabilitas pangan usia dini dengan kejadian picky eater. Namun, ada hubungan antara tekanan untuk makan dengan kejadian picky eater. Perlu dilakukan kegiatan penyuluhan kepada ibu mengenai praktik pemberian makanan yang tepat, yaitu cara pemberian makan tanpa tekanan agar tidak terjadi kesulitan makan pada anak. Informasi ini dapat disampaikan saat posyandu atau pertemuan rutin Pembinaan Kesejahteraan Keluarga (PKK). Perlu adanya penelitian longitudinal lanjutan dengan besar sampel yang mempertimbangkan berbagai faktor perancu untuk dapat menggali faktor-faktor terkait pola makan usia dini dikaitkan dengan perilaku picky eater saat usia 2-3 tahun seperti praktek pemberian ASI dan MP-ASI. 


\section{UCAPAN TERIMA KASIH}

Penulis mengucapkan terimakasih kepada Politeknik Kesehatan Kementerian Kesehatan Malang yang telah memberikan dana sehingga penelitian ini dapat terlaksana.

\section{Pernyataan konflik kepentingan}

Penulis menyatakan tidak ada konflik kepentingan dengan pihak-pihak yang terkait dalam penelitian ini.

\section{RUJUKAN}

1. Wooldridge NH. Toddler and preschooler nutrition. In: Brown JE, editors. Nutrition through the life cycle. 4th ed. California: Wadsworth, Cengage Learning; 2011.

2. National Health and Medical Research Council. Infant feeding guidelines. Canberra: National Health and Medical Research Council; 2012.

3. Ekstein S, Laniado D, Glick B. Does picky eating affect weight-for-length measurements in young children?. Clin Pediatr (Phila) 2010;49(3):217-20.

4. Tharner A, Jansen PW, Jong JCK, Moll HA, Ende JVD, Jaddoe VWV, et al. Toward an operative diagnosis of fussy / picky eating: a latent profile approach in a population-based cohort. Int J Behav Nutr Phys Act 2014;11(14):11-14.

5. Shim JE, Kim J, Mathai RA. Associations of infant feeding practices and picky eating behaviors of preschool children. J Am Diet Assoc 2011;111(9):1363-8.

6. Carruth BR, Ziegler PJ, Gordon A, Barr SI. Prevalence of picky eaters among infants and toddlers and their caregivers' decisions about offering a new food. J Am Diet Assoc 2004;104(1):57-64.

7. Cano SC, Tiemeier H, Hoeken D Van, Tharner A, Jaddoe VWV, Hofman A, et al. Trajectories of picky eating during childhood : a general population study. Int J Eat Disord 2015;48(6):570-9.

8. Imawati. Kaitan antara pengasuhan dan kesulitan makan dengan status gizi balita di Kelurahan Loktabat Selatan Kotamadya Banjarbaru Provinsi Kalimantan Selatan [Skripsi]. Yogyakarta: Universitas Gadjah Mada; 2010.

9. Ashman AM, Collins CE, Hure AJ, Jensen M, Oldmeadow C. Maternal diet during early childhood, but not pregnancy, predicts diet quality and fruit and vegetable acceptance in offspring. Matern Child Nutr 2016:12(3)579-90.

10. Fisk CM, Crozier SR, Inskip HM, Godfrey KM, Cooper C. Influences on the quality of young children's diets: the importance of maternal food choices. Br J Nutr 2011;105(2):287-96.

11. Gugusheff JR, Ong ZY, Muhlhausler BS. A maternal "junk-food" diet reduces sensitivity to the opioid antagonist naloxone in offspring postweaning. FASEB J 2013;27(3):1275-84.

12. Galloway AMYT, Fiorito L, Lee Y, Birch LL. Parental pressure, dietary patterns, and weight status among girls who are "picky eaters". J Am Diet Assoc 2005;105(4):541-8.

13. Gregory JE, Paxton SJ, Brozovic AM. Pressure to eat and restriction are associated with child eating behaviours and maternal concern about child weight, but not child body mass index, in 2-to 4-year-old children. Appetite 2010;54(3):550-6.

14. Powell FC, Farrow CV, Meyer C. Food avoidance in children. The influence of maternal feeding practices and behaviours. Appetite 2011;57(3):683-92.

15. Galloway AT, Lee Y, Birch LL. Predictors and consequences of food neophobia and pickiness in young girls. J Am Diet Assoc 2003;103(6):692-8.

16. Coulthard H, Harris G, Emmett P. Delayed introduction of lumpy foods to children during the complementary feeding period affects child's food acceptance and feeding at 7 years of age. Matern Child Nutr 2009;5(1):75-85.

17. Dubois L, Farmer A, Girard M, Peterson K, Tatone-tokuda F. Problem eating behaviors related to social factors and body weight in preschool children: a longitudinal study. Int J Behav Nutr Phys Act 2007;4(9):1-10.

18. Anggraini IK. Perilaku makan orang tua dengan kejadian picky eater pada anak usia toddler. Jurnal Keperawatan 2014;5(2):154-62.

19. Lwanga S, Lemeshow S. Sample size determination in health studies: a practical manual. Geneva: World Health Organization; 1991.

20. Suresh K, Chandrashekara S. Sample size estimation and power analysis for clinical research studies. J Hum Reprod Sci 2012;5(1):7-13.

21. Savige GS, Hage BH, Wahlqvist ML. Food variety as nutritional therapy. Current Therapeutics [series online] 1997 [cited 2015 Nov 4]. Available from: URL: http://apjen.nhri.org.tw/server/info/articles/diet-guide/ foodvariety 1997.pdf

22. Birch LL, Fisher JO, Grimm-Thomas K, Markey CN, Sawyer R, Johnson SL. Confirmatory factor analysis of the child feeding questionnaire: a measure of parental attitudes, beliefs and practices about child feeding and obesity proneness. Appetite 2001;36(3):201-10.

23. Wardle J, Guthrie CA, Sanderson S, Rapoport L. Development of the children's eating behaviour questionnaire. J Child Psycol Psyciat 2001;42(7):96370.

24. Dewar G. The science of picky eaters why kids reject foods that you like. Parenting Science [series online] 2013 [cited 2015 Nov 4]. Available from: URL: http://www. parentingscience.com/picky-eaters.html. 
25. Capaldi ED, Privitera GJ. Decreasing dislike for sour and bitter in children and adults. Appetite 2008;50(1):13945.

26. Finistrella V, Manco M, Ferrara A, Rustico C, Presaghi F, Morino G. Cross-sectional exploration of maternal reports of food neophobia and pickiness in preschooler-mother dyads. J Am Coll Nutr 2012;31(3):152-9.

27. Nicklaus S. Children's acceptance of new foods at weaning. Role of practices of weaning and of food sensory properties. Appetite 2011;57(3):812-5.
28. Dovey TM, Staples PA, Gibson EL, Halford JCG. Food neophobia and 'picky/fussy' eating in children: a review. Appetite 2008;50(2-3):181-93.

29. Savage JS, Fisher JO, Birch LL. Parental influence on eating behavior. J Law Med Ethics 2008;35(1):22-34.

30. Musher-eizenman D, Holub S. Comprehensive feeding practices questionnaire: validation of a new measure of parental feeding practices. J Pediatr Psychol 2007;32(8):960-72. 